\title{
Post-Industrial Tourism as \\ a Means to Revitalize the Environment of the Former Oil Basin in the Polish Carpathian Mountains
}

\author{
Zygmunt Kruczek $^{1 *}$, Michał Kruczek ${ }^{2}$ \\ ${ }^{1}$ Department of Natural Environmental Studies, Faculty of Tourism and Recreation, \\ University of Physical Education in Krakow \\ ${ }^{2}$ Department of Biochemistry, Institute of Plant Biology and Biotechnology, Faculty of Horticulture, \\ University of Agriculture in Krakow
}

Received: 28 January 2015

Accepted: 14 November 2015

\begin{abstract}
The oldest oil field in the world, located in the Polish Carpathian Mountains, is ending its production activity. Former mines and distilleries have become technological heritage sites, and many structures are in need of revitalisation. Post-industrial tourism presents an opportunity for rescuing industrial heritage and protecting the natural environment. The focus of this article is on the mining and oil industry traditions in the Polish Carpathian Mountains, and the region's heritage is evaluated in terms of tourist attraction. The authors concentrate on the possibilities of using oil routes for post-industrial tourism as a means to revitalise post-industrial sites and ensure sustainable development for the region. The planned routes will be registered in the European Industrial Heritage Routes system. A SWOT analysis was conducted for the Carpathian oil route, and attention was drawn to the benefits for the natural environment and local communities resulting from the creation of tourist routes.
\end{abstract}

Keywords: Polish Carpathians, oil industry monuments, revitalisation, theme routes

\section{Introduction}

By the end of the $20^{\text {th }}$ century tourism had become a widespread phenomenon - something very commonplace that most members of society could not imagine living without. Despite local wars, terrorist attacks, epidemics, and cataclysms such as earthquakes and tsunamis, worldwide tourism has developed dynamically. According to experts

*e-mail: zygmunt.kruczek@awf.krakow.pl of the United Nations World Tourism Organization (UNWTO), more than 1 billion tourists travelled around the world in 2014, while the domestic tourist movement is estimated at 4 billion people [1]. Tourism is currently an important part of national economies, and has provided an opportunity for many countries to develop and spur regional growth. The growth of tourism should follow the principles of sustainable development - in other words, it needs to remain in harmony with the natural and social environments. The task of both the national administration 
and local councils is to support the kind of tourism that is environmentally friendly in rural and urban areas. These forms of tourism include soft tourism, as well as ecological tourism, farm tourism, and active tourism. Additionally, cultural tourism has become a phenomenon of the $21 \mathrm{st}$ century. This term refers to all group or individual trips of a touristic character during which the travellers have contact with sites or events that are either of value for high or popular culture, or that serve to expand their knowledge of the world [2, 3]. Cultural tourism also includes visits to industrial heritage sites. This is often referred to as industrial tourism or, in the case of visits to industrial sites that are no longer operational, post-industrial tourism.

The establishment and development of industrial tourism was triggered by the recognition of technological structures as monuments to past eras, and appreciation of their cultural and artistic value. The growing significance of industrial tourism has had a positive impact on regional development and an influence on economic growth, and can mitigate the effects of industrial restructuring in job markets through the creation of new positions in the service sector. Making use of technological heritage resources for tourism is advantageous to economic development both on local and nationwide scales. It is estimated that global earnings from industrial tourism have already reached $\$ 9$ billion US annually [4]. Industrial tourism increases the touristic attractiveness of selected areas, and in this way strengthens the economic potential of regions.

In the Polish and Ukrainian Carpathian Mountains, mines and refineries have been preserved that date from the mid- $19^{\text {th }}$ century - the period that marks the beginnings of the oil industry in Poland $[5,6]$. In order to protect them from becoming dilapidated or forgotten, it is necessary to place them under special protection and give them the status of heritage sites. Transforming the function of a region from industrial to touristic can be beneficial to the natural environment and can help stabilise the development of former oil fields.

Places that remain from the pioneer era of petroleum exploitation constitute one of many problems for environmental protection in the Carpathian Mountains and foothills [7]. They are areas where wells were dug in the $19^{\text {th }}$ century for the exploitation of petroleum, rock wax, asphalt, and other minerals. These hand-dug wells have been left in various states. Some of the areas in which the wells are located belong to private individuals. The wells can often be found in mountainous and forested terrain, or in legally protected areas, but also in open areas close to agricultural and residential buildings, where they are covered in soil. In the Polish Carpathians, more than 500 structures of this kind have been catalogued. Due to the breakdown of the geological structure of the rock mass, the wells are a source of petroleum and gas emissions. They pose a direct threat to the environment, and are often already causing damage [7]. Many of these wells are suitable for protection by connecting them with proposed oil routes, as was done in a mining heritage park (the Museum of Oil and Gas Industry in Bóbrka). After being cleaned and made secure, the wells were added to an exhibition depicting the history of petroleum exploitation, and no longer pose a threat to people, animals, the soil, or plants [8].

The aim of this paper is to evaluate the possibility of protecting and promoting industrial heritage connected with the petroleum industry in the Polish Carpathian Mountains, as well as revitalising the cultural landscape and preserved structures dating from the era of the Galician petroleum rush, in the form of theme routes for tourists. This is important not only in terms of reducing potential ecological harm, but because of the educational aspect and maintaining sustainable development.

The starting point for realising this aim is to show the positive role of tourism in the sustainable development of regions where there is a tourist movement. A change in the use of petroleum industry sites influences their new functions, and making use of them for tourism should become an element of sustainable development of a region and thus the protection of that region's natural environment. These sites, treated as tourist attractions, could aid the creation of theme routes and tourist products associated with them [9].

This paper is based on an analysis of international and Polish specialist literature related to post-industrial sites that have been acknowledged as part of Europe's oil industry heritage and the museums connected with it. In order to demarcate oil routes, an inventory of structures connected to the oil industry in the Polish Carpathians was carried out. A SWOT analysis was also conducted for a cross-border oil route project in the Polish and Ukrainian Carpathian Mountains.

\section{Sustainable Development and Tourism}

Sustainable development in tourism meets the current needs of both tourists and the regions that are visited, protecting and expanding future opportunities. In the UNWTO policy guidelines, this development is designated as a principle for managing all resources in such a way as to allow economic, social, and aesthetic needs to be satisfied through the simultaneous preservation of cultural integrity, the essence of ecological processes, and biological diversity [9].

It is important to ensure that the local population is aware of the principles of sustainable development and to create conditions that allow local inhabitants to participate in all endeavours connected with tourism that are undertaken in their areas. This applies to the creation of tourist products involving local natural, human, and material resources. The development of tourism should be integrated with local economic development in order to be ethically, socially, and economically favourable for the local population [10].

Similarly to other branches of the economy such as industry [11] and agriculture [12], an important aspect in tourist services is the search for rational ways of managing energy and limiting pollution of the natural environment [6]. Although the share of the tourism industry in the 
production of greenhouse gases and other pollutants is not as large as in heavy industry [13], national governments and international agencies are nevertheless trying to rationalize consumption of natural resources and energy by defining standards and capping emissions of gases, especially $\mathrm{CO}_{2}$ [14]. According to preliminary estimates [4], tourist consumption generates about $6-8 \%$ of air pollution. Of particular concern is the problem of rational energy use. This concerns not only the use of fuel by tourists while travelling and the consumption of water in hotels, but also the costs of heating seasonal structures, the annexation of space for tourists, and devastation of the natural landscape.

In 2008, during the IUCN World Conservation Congress in Barcelona, a set of global sustainable tourism criteria were laid out on the initiative of UNEP, UNTWO, and the Rainforest Alliance. Sustainable tourism is integrated with the development of other branches of a region's economy (agriculture, forestry, municipal farming, industry, and transportation), as well as the economic activity and lives of the region's inhabitants [15]. In countries with dynamic industrial development there are many examples of ineffective resource policies [16], which causes huge loss not only in economic terms but also in social and ecological aspects. For the reduction or elimination of such losses there is a great need for suitable pro-ecological policies, especially concerning ways of maintaining sustainable development. Sustainable management in tourism involves, above all, the careful management of natural resources and space as well as the use of touristic and paratouristic infrastructures that already exist $[6,17]$.

\section{Oil Industry Heritage in the Polish Carpathian Mountains as a Tourist Attraction}

Tourist attractions can be defined most succinctly as anything that interests tourists or a characteristic place, often unique, for example a natural environment or a historical monument, and events such as festivals and sports matches [18]. Tourist attractions have been specified in a similar way by Swarbrooke [19], who states that tourist attractions include any and all elements that incite people to leave their homes.

Nowadays, technology heritage sites are important tourist attractions [19]. These include old mines, factories, workshops, buildings, construction, vehicles, machines, tools, scientific instruments, and products that are particularly characteristic for former and contemporary forms of farming, technology, and science. The International Centre for the Documentation and Study of Industrial Heritage for Tourism located in Zabrze, Poland, is broadening the concept of industrial heritage to include such phenomena resulting from industrial production as lifestyle, landscape, customs, traditions, events, and art from both the past and the present [20].

Industrial tourism is growing dynamically, especially in Western European countries where many cities have industrial traditions, such as Manchester and Birmingham in Great Britain, the cities of the Ruhr Valley in Germany, and the industrial districts of Oslo, Berlin, and Amsterdam. In these locations industrial functions have been transformed so as to perform touristic, commercial, residential (so-called lofts), and cultural functions. Industrial structures are becoming equally as attractive to tourists as art museums, wonderful works of architecture, and historical sites. An important issue for industrial tourism is the interactivity of an attraction (the ability to use old equipment, the opportunity to sample or purchase products, the chance to take a ride in historical vehicles, etc.) $[21,22]$.

On Poland's cultural landscape it is possible to distinguish many centres where technical traditions have developed that are worthy of being presented to the contemporary tourist. Such traditions include the development of mining technology, beginning with the primitive flint mines in Krzemionki Opatowskie, through the technology of the salt mine in Wieliczka, ore mining near Olkusz, the mining of zinc and lead ores in the vicinity of Tarnowskie Góry, the methods of extracting petroleum oil in Bóbrka (near Krosno), and the coal mining technology of our times. The register of technological heritage sites in Poland already contains 1,500 sites from many diverse branches of industry.

Economic activity and technological heritage sites are also featured in numerous specialist museums that present the development of various branches of the economy, as well as technological changes and production methods. The popularity of technological heritage sites is connected with the dynamic growth of post-industrial tourism as one of the forms of cultural tourism. The Industrial Heritage Route of the Silesian Voivodeship, created in Poland in recent years, has become a tourist product based on industrial heritage. It is actually a tourist product network currently consisting of 36 industrial tourist attractions [7]. A similar role is filled by the Krakow Industrial Heritage Route - the only urban route that makes use of postindustrial heritage [23].

Poland is the cradle of the world's oil industry. The date of its birth is considered to be 1853 , when a kerosene lamp, constructed by Ignacy Łukasiewicz, was lit for the very first time in a hospital in Lvov. In the middle of the $19^{\text {th }}$ century the first petroleum wells appeared, next to which distilleries were established - the world's first being established in 1858 in Ulaszowice, near Jasło. In 1886, 12 oil distilleries and three refineries were operational in Galicia. Ziemia Gorlicka was the area of Galicia, where the greatest amounts of oil were extracted. In 1881, with a production of 40,000 tons of oil, Galicia held third place in the world, after the USA and Russia, and half of this extracted oil came from the Gorlickie Basin [6, 24].

An exceptional concentration of oil industry heritage sites can be found in the Jasielski, Garlicky, and Krośnieński districts (such as the heritage park in Bóbrka, the Oil Industry Museum in Libusza, and the Sub-Carpathian Museum in Krosno). Mines established in 1854-87 and that are still operational today are in Bóbrka, 
Table 1: Oil and Gas Industry Museums in Europe.

\begin{tabular}{|c|c|c|c|c|}
\hline LP & Name & Country & Established & Exhibition \\
\hline 1 & $\begin{array}{l}\text { National Museum of Oil } \\
\text { Industry, Ploesti }\end{array}$ & Romania & 1957 & Extensive collections of machines and tools. \\
\hline 2 & $\begin{array}{l}\text { Museum of Oil and Gas } \\
\text { Industry, Bóbrka }\end{array}$ & Poland & 1961 & $\begin{array}{l}\text { A collection of objects and documents connected with } \\
\text { the oldest oil petroleum mine, founded in } 1854 \text {, which } \\
\text { is still operational. }\end{array}$ \\
\hline 3 & $\begin{array}{l}\text { Museum of the Hungarian Oil } \\
\text { Industry, Zalaegerszeg }\end{array}$ & Hungary & 1969 & $\begin{array}{l}\text { Many large machines dating chiefly from the } 20^{\text {th }} \\
\text { century connected to the extraction of crude oil, such } \\
\text { as drilling rigs, boring engines, beam pumps and } \\
\text { compressors. }\end{array}$ \\
\hline 4 & $\begin{array}{l}\text { Musée du pétrole de Merkwiller- } \\
\text { Pechelbronn }\end{array}$ & France & 1967 & $\begin{array}{l}\text { A collection mainly consisting of documents, photos, } \\
\text { models, exhibits and oil industry equipment. }\end{array}$ \\
\hline 5 & $\begin{array}{l}\text { German Petroleum Industry, } \\
\text { Wiese }\end{array}$ & Germany & 1970 & $\begin{array}{l}\text { A collection including derricks, valves, pumps and the } \\
\text { 'nodding donkeys' used to extract crude oil from the } \\
\text { ground. There is a geological section explaining how } \\
\text { oil and gas are formed. }\end{array}$ \\
\hline 6 & $\begin{array}{l}\text { Museum of the Petroleum } \\
\text { Industry, Stavanger }\end{array}$ & Norway & 1999 & $\begin{array}{l}\text { An exhibition presenting the technology of oil } \\
\text { exploration and pumping, and the way of life of those } \\
\text { who worked on the platforms. }\end{array}$ \\
\hline 7 & $\begin{array}{l}\text { Scottish Shale Oil Mines } \\
\text { Light Railway, Almond Valley } \\
\text { Heritage Centre, Millfield }\end{array}$ & UK & 1983 & $\begin{array}{l}\text { Exhibits presenting the history of the oil industry, and } \\
\text { the starting point for a heritage trail that passes through } \\
\text { shale-working villages. }\end{array}$ \\
\hline 8 & $\begin{array}{l}\text { Oljeon. Analberg, Oil island in } \\
\text { Lake Amannigen }\end{array}$ & Sweden & 1986 & $\begin{array}{l}\text { A refinery dating from the pioneer years of the oil } \\
\text { industry, preserved at Angelsberg on Oljeon (oil island) } \\
\text { in Lake Amannigen, near the Engelsberg ironworks, } \\
\text { part of the Bergslagen Ekomuseum. }\end{array}$ \\
\hline 9 & $\begin{array}{l}\text { Oil Shale Museum Kaevanspark, } \\
\text { Jaama }\end{array}$ & Estonia & 2001 & $\begin{array}{l}\text { A collection of oil paintings of mines, and a display of } \\
\text { equipment which includes Esku, a 50-tonne bucket. }\end{array}$ \\
\hline
\end{tabular}

Source: the author's own work

Wietrzno, and Rivne. The mining infrastructure has also been preserved - here one can find pumpjacks, horse mills, oil tanks, smithies, and workshops [25].

An effective way to protect and revitalise these sites is through the creation of theme routes aimed at tourists who are interested in culture. It is important to note that several routes of this type have been created in the Krośnieński and Gorlicki districts. Unfortunately, they are still only in the initial stages of development.

\section{European Routes of Industrial Heritage}

At the end of the 1980s, the Council of Europe began carrying out a project called the European Cultural Route. Its aim was to make Europeans aware of their cultural identity and European citizenship; to encourage Europeans to preserve and protect heritage as a source of social, economic, and cultural development of the places in which they live; and to endow places connected to cultural tourism with special significance while maintaining the principles of sustainable development [26, 27].

Within the framework of the rich European Cultural Route system, the European Route of Industrial Heritage (ERIH) comprises a network that unites more than 850 post-industrial heritage sites, such as post-industrial landscapes, non-operational industrial complexes, and individual plants. This network came into being as a result of cooperation between European partners in Germany, the UK, and Holland, and is financed within the framework of the Interreg II project. The ERIH project was modelled on the Industrial Heritage Route in the Ruhr Valley. Poland also joined this system, represented by the Industrial Heritage Route of the Silesian Voivodeship. ERIH functions on the basis of so-called anchor points places of particular importance for post-industrial heritage from which minor regional and theme routes branch out (http://www.erih.net, accessed 05.01.2015). In 2014 there were 72 anchor points, of which five were located in Poland (the "Guido" Historical Coal Mine in Zabrze, the Historical Silver Mine in Tarnowskie Góry, the Tyskie Brewing Museum in Tychy, the Brewery Museum in Żywiec, and the Textile Museum Factory in Łódź). The ERIH routes connect roughly 1,000 places in 44 countries, organized into thematic and regional routes. These routes are generally not signposted owing to the considerable distances between specific sites.

The extraction and processing of petroleum oil was added to the ERIH system to a route thematically connected with energy. Apart from numerous museums 
connected with city gasworks, particularly worthy of attention are places connected with the extraction and processing of petroleum oil. There are not many of these only 10 in total. They are presented in Table 1.

The oldest sites of this type were established in Romania and Poland. The Museum of the Oil and Gas Industry in Bóbrka is in the form of a heritage park spread over an area of 20 hectares on the site of the former Bóbrka mine. There is an outdoor exhibition of drilling and extraction equipment, preserved mining buildings, and other structures documenting the development of the oil industry [8]. The museum in Bóbrka should fulfil the function of an anchor point on the cross-border oil route.

\section{The Carpathian Oil Routes}

\section{The Jasło-Lvov Cross-Border Oil Route}

This route was created in 2002 on the occasion of the $180^{\text {th }}$ anniversary of I. Lukasiewicz's birthday and the $120^{\text {th }}$ anniversary of his death, on the initiative of the Beskid Niski Local Tourism Organization in Krosno, in collaboration with the district authorities of southern Subcarpathia and partners from Ukraine within the framework of the PHARE 2002 project [28].

This route leads across the Subcarpathian oil and gas industry areas in Poland and Ukraine and runs through the historical region of Galicia. The main aim of its creation was to rescue relicts of the oil industry from oblivion, promote the region, and create a tourist product. The route connects such towns as Bóbrka, Jedlicze, Zarszyn, Strachocina, Sanok, Tyrawa Solna, Wielopole, Niżankowice, Chyrów, Stary Sambor, Sambor, Drohobych, Borysław, and Truskawiec (Fig. 1).

The route links places connected with the birth and history of the oil industry in areas belonging to AustroHungarian Galicia in the second half of the $19^{\text {th }}$ century. The route was marked out in such a way as to allow a tourist interested in the subject of oil to simultaneously become acquainted with wonderful secular and religious sites of intermingling cultures characteristic of the borderlands, as well as the precious features of the natural environment in the Bieszczady, Beskid Niski, Pogórze Karpackie, and Doły Jasielsko-Sanockie areas. The main axis of the route designed for motorized tourists is the route leading from Jasło through Krosno, Sanok, Lesko, Ustrzyki Dolne, Sambor, Borysław, and Drohobych to Lvov. This route has been enhanced with a loop designated for tourists travelling on foot and by bicycle [28].

\section{The Carpathian-Galician Oil Route}

This route can be treated as the initial section of the cross-border route, that is its extension toward the west. It was created on the initiative of the Gorlice County municipal authorities as well as the Beskid Zielony Local Tourism Organisation. The route features numerous places and sites documenting the history and activity of the pioneers of the oil industry, selected according to the following criteria: uniqueness, historical value, artistic value of the natural and cultural surroundings, and accessibility for visitors. The route leads through 13 towns: Gorlice, Ropica Polska, Szymbark, Ropa, Łosie, Bielanka, Siary, Sękowa, Kryg, Kobylanka, Lipniki, Libusza (the Oil Industry and Ethnography Museum), and Zagórzany. A revitalisation project of areas connected to oil mining in the vicinity of Gorlice is currently being carried out. An oil mining heritage theme park is currently being constructed on the site of the Magdalenka Mine, and there are plans for land reclamation on the post-industrial sites of the Glimar SA oil refinery. Realisation of these projects in Gorlice will allow the role and significance of Gorlice in the development of both the domestic and worldwide oil industry to become more widely known. The site that is located the furthest to the west on this route is the former oil refinery in Sowliny, near Limanowa [29].

Other tourist routes have also been proposed. One of these is an educational trail called "The World's Cradle of Oil Mining," which would lead through towns connected with the development of the oil industry (Bóbrka,

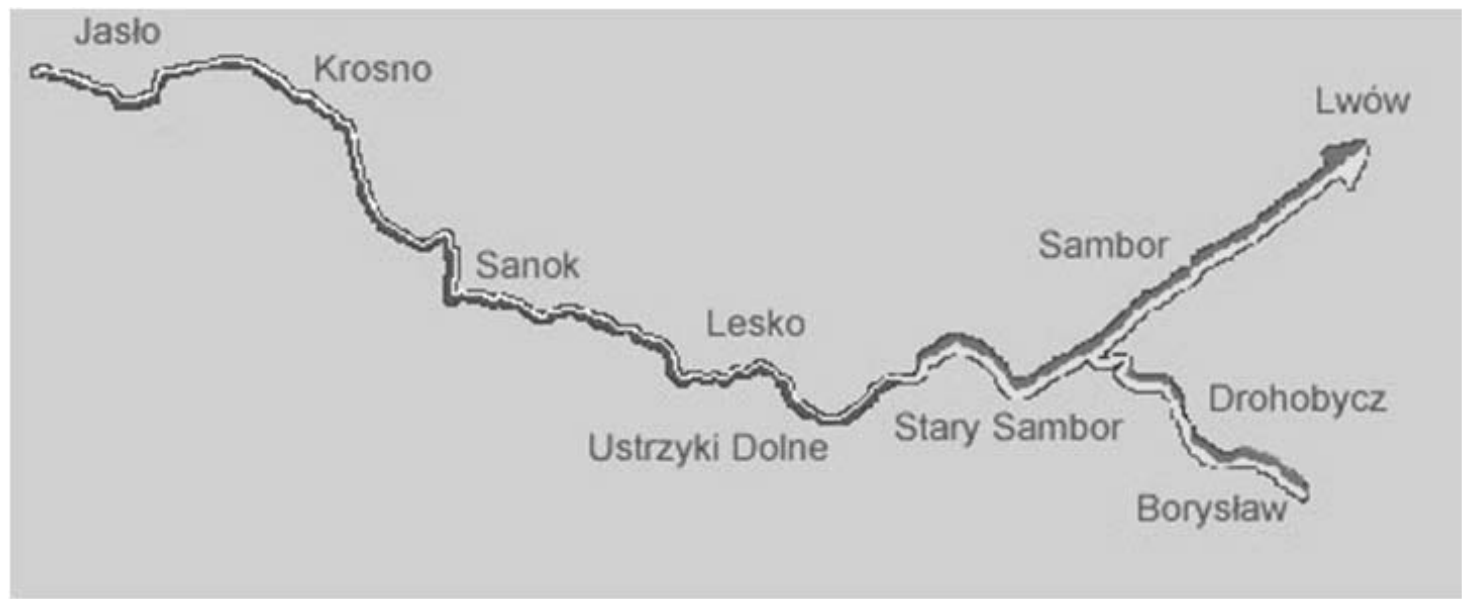

Fig. 1. Diagram of the Cross-border Oil Route. 
Table 2: SWOT Analysis for a Cross-border Oil Route Project.

\begin{tabular}{|c|c|}
\hline STRONG POINTS & WEAK POINTS \\
\hline $\begin{array}{l}\text { - The unique character of monuments connected with mining } \\
\text { and processing of petroleum oil. } \\
\text { - } \text { Historic traditions - the cradle of the world's petroleum } \\
\text { industry. } \\
\text { - Establishment of the Museum of Oil and Gas Industry } \\
\text { in Bóbrka as an anchor point in the European Route of } \\
\text { Cultural Heritage. } \\
\text { - Location of post-industrial sites in the Beskid and Pogórze } \\
\text { landscapes, high aesthetic value. } \\
\text { - Close proximity of national parks and nature reserves. } \\
\text { - Historic arrangement and settlement of towns and villages, } \\
\text { sacred monuments (churches, Orthodox churches, } \\
\text { synagogues) registered on the UNESCO list, palaces, } \\
\text { castles, manor houses. } \\
\text { - Numerous museums, heritage parks and galleries on the oil } \\
\text { route (Gorlice, Jasło, Krosno, Żarnowiec, Sanok, Ustrzyki } \\
\text { Dolne, Sambor, Drohobych, Lviv. } \\
\text { Considerable potential for tourism organisers, hotels and } \\
\text { restaurants, which are necessary for the creation of a } \\
\text { network tourist product. } \\
\text { Personnel resources - aficionados of petroleum oil, } \\
\text { volunteers, local tourism organisations and a council of } \\
\text { people interested in creating and commercially promoting } \\
\text { the oil route. }\end{array}$ & $\begin{array}{l}\text { - The low accessibility of the region - the lack of quick trans- } \\
\text { European and domestic transport connections. } \\
-\quad \text { The low accessibility of particular sites on the route. } \\
-\quad \text { The significant length of the trail and its route through various } \\
\text { administrative centres. } \\
-\quad \text { Reluctance of entities and organisations to cooperate in the cre- } \\
\text { ation of network tourist products. } \\
-\quad \text { Low awareness in society of the value of post-industrial sites, } \\
-\quad \text { The poor technical state of many sites on the route. } \\
-\quad \text { The underestimation of the value of the local culture and natural } \\
\text { environment. } \\
-\quad \text { Lack of consistent signs marking the routev } \\
-\quad \text { Insufficient promotion of mining and oil industry monuments as } \\
\text { tourist attractionsv } \\
-\quad \text { Lack of package tour offers for the oil route, low interest among } \\
\text { tour operators for creating such offers. } \\
\text { - Weak tourism management of the Ukrainian section of the route. }\end{array}$ \\
\hline & \\
\hline 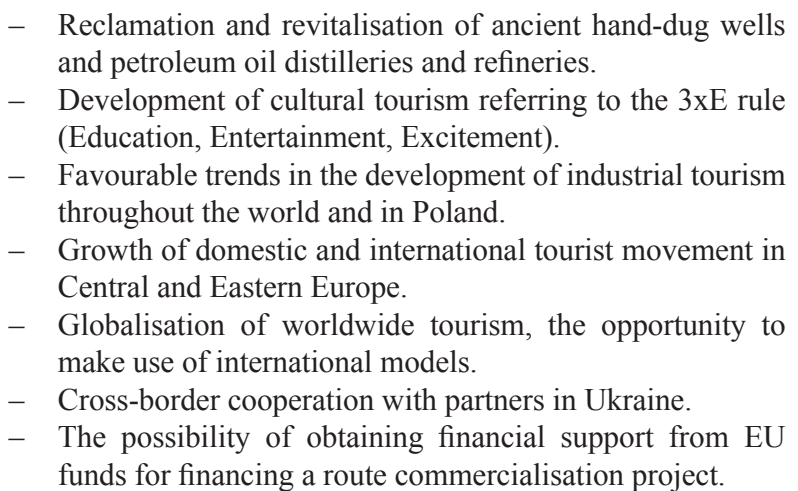 & 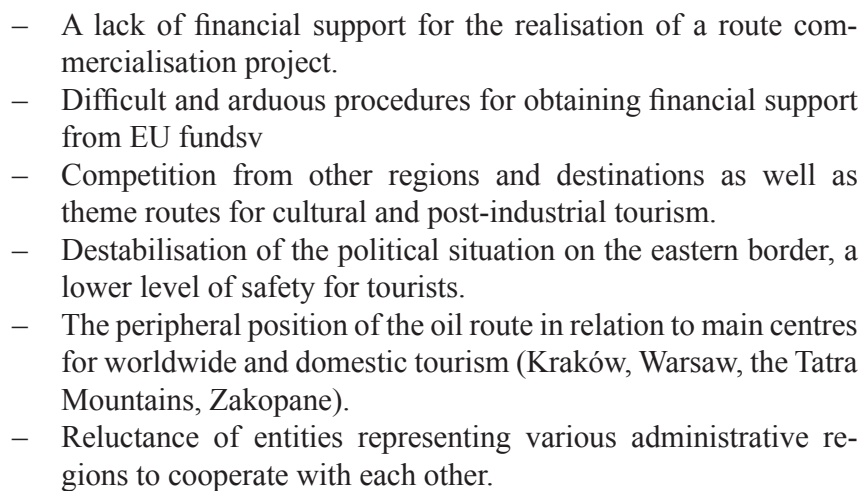 \\
\hline
\end{tabular}

Source: the author's own work

Chorkówka, Krosno, Rogi, Wietrzno, and Równe), and also with the exploitation of mineral waters in IwoniczZdrój and Rymanów-Zdrój [22]. The second is a crossborder geotourist trail called "In the Tracks of Extinct Giant Mammals, Earth Wax, Petroleum Oil and Salt," connecting such places as: Starunia (a place where woolly rhinoceroses have been discovered in earthwax deposits), Borysław - Lvov - Bóbrka (places connected with the oil industry), and Wieliczka (the salt mine that has been placed on the UNESCO World Heritage List) - Kraków (natural history museums) [25].

The creation of thematic routes associated with the mining and oil industries offers an opportunity to revitalise a region of outstanding natural beauty, but which is also one of the poorest regions in Poland. It is necessary to pose the question of whether post-industrial tourism offers opportunities for protecting natural resources and the landscape, while at the same time creating new workplaces and sources of income for the local community. The answer to this question may be obtained by performing a SWOT analysis.

The SWOT method allows strengths and weaknesses as well as opportunities and threats to be identified [30]. This method is used in all areas of strategic planning as a universal tool at the first stage of analysis. Strengths and weaknesses involve events related to the subject of analysis, while opportunities and threats are external conditions. A SWOT analysis is a strategic analysis algorithm, a summary of the overall assessment of the current condition and development potential. SWOT analysis has been used in market research, but has also been successfully applied to tourism projects [31].

In the SWOT analysis presented below, both the strong and weak points of the projects are indicated - the chance of their realisation as well as the real dangers. 


\section{Conclusions}

Oil industry and mining structures and equipment that have been preserved in the Polish and Ukrainian Carpathian Mountains are of high value for cultural heritage, since they document the creation and global development of the oil industry - the cradle of which is located here in this very place. Their dispersal and poor technical state are an incentive to work toward protecting this heritage and making it accessible to the needs of the tourism industry. The growing popularity of industrial tourism throughout the world and within Poland presents an opportunity to create tourist products based on attractions connected with post-industrial sites. The best way to popularise post-industrial heritage and revitalise the natural environment is through these planned oil routes.

The revitalisation of the former oil basin as a tourist region by making use of post-industrial sites could also benefit the local community by creating new work opportunities, contributing to the development of infrastructure and improving the economic conditions of this comparatively poor region of Poland.

The SWOT analysis performed for the Carpathian Oil Routes indicates significant benefits and opportunities, allowing for the adoption of a maxi-maxi strategy [31]. This involves product diversification and acquiring new customers.

Realisation of this project and successful achievement of the desired results requires the cooperation of all entities interested in the routes, namely the municipal authorities, local tourist organizations, and entities providing services for tourists. The analysed routes do not meet the criteria for a tourist product on account of the lack of a commercialisation process for them [17]. Cooperation between economic entities is essential, as is the creation of tourist packages and chain products. These activities should receive governmental support through the facilitation of efforts to obtain financing from EU funds allocated to cross-border cooperation. Successful examples of the functioning of similar routes in Poland and Western Europe (e.g., the Industrial Heritage Route of the Silesian Voivodeship or Zollverein in the Ruhr Valley) will provide a model for the creation and maintenance of the Carpathian oil routes [20].

\section{References}

1. UNWTO Tourism Highlights, 2014 Edition. www.http:// publications.unwto.org/. 14.01.2015.

2. MIKOS VON ROHRSCHEIDT A., Cultural tourism. The phenomenon, potential, prospects. Gniezno 2008 [In Polish only].

3. RICHARDS H., Cultural Tourism. Global and Local Perspective. New York Howart, 2007.

4. Industrial Heritage and Agri/Rural Tourism in Europe. European Parliament's Committee on Transport and Tourism. Brussels, 2013. European Union. (http://www. europarl.europa.eu/studies).
5. JAWOR E., KRUCZEK J., Geology of oil and gas deposits (In :) Wolwowicz R. (ed.) History of Polish oil industry. Brzozów-Kraków: 61-159. 1994 [In Polish only].

6. ZUZAK J., The Guide. The Ignacy Łukasiewicz Memorial Museum of Oil Industry in Bóbrka. Museum of oil and gas industry foundation, Bóbrka, 2009.

7. LIPIŃSKA E.J., Heritage or environmental risk of remains of ancient works of oil mining? In: Innovative revitalization of degraded areas? W: Innowacyjne rozwiązania rewitalizacji terenów zdegradowanych, Red. J. Skowronek. Centrum Badań i Dozoru Górnictwa Podziemnego Sp. z o.o. w Lędzinach, Instytut Ekologii Terenów Uprzemysłowionych w Katowicach, Katowice 2009 [In Polish only].

8. BOBEK CZ., WAIS T., Mining liquidation and reconstruction of nineteenth-century pits on the example of the Museum of Oil and Gas Industry to them. Ignacy Lukasiewicz in Bóbrka. [In] I Conference of Mining Museums and Underground Skansens in Poland. Muzeum Żup Solnych. Wieliczka 2010. [in Polish only].

9. JANSEN-VERBEKE M., Industrial heritage: A nexus for sustainable tourism development. Tourism Geographies, 1 (1), 70, 1999.

10. ZARĘBA D., Ecotourism, PWN, Warszawa 2010 [In Polish only].

11. ZHAOHUA WANG, CHEN WANG, JIANHUA YIN, Strategies for addressing climate change on the industrial level: affecting factors to $\mathrm{CO} 2$ emissions of energy intensive industries in China, Nature Hazards. 2/2014.

12. Agriculture and the Environment: Issues and Policies. OECD, Paris 1998

13. ZHANG BIN, ZHAOHUA WANG, Inter-firm collaborations on carbon emission reduction within industrial chains in China: practices, drivers and effects on firms' performances, Energy Economics, 42, 115, 2014.

14. Climate Change 2014. Synthesis Report. Intergovernmental Panel on Climate Change (http://www.ipcc.ch/pdf/ assessment-report/ar5/syr/SYR_AR5 FINAL full wcover. pdf; access 30.11.2015).

15. BUTCHER J., Ecotourism as Life Politics, Journal of Sustainable Tourism, 16 (3), 315, June 2008.

16. ZHAOHUA WANG, CHAO FENG, Sources of production inefficiency and productivity growth in China: A global data envelopment analysis, Energy Economics, 49, 380, 2015.

17. GAWEŁ Ł., Cultural heritage routes - management practice. Reflections after the audit of the Silesian Industrial Monuments Route, Turystyka Kulturowa 2/2012 [In Polish only].

18. GOODALL B.,The Dynamics of Tourism Place Marketing. [in:] ed. Ashworth G., Goodall B., Marketing Tourism Places, London, Routledge. 1990.

19. SWARBROOKE J. The development and management of visitors attractions, Butterworth - Heinemann, Oxford 2002.

20. Industrial heritage as part of sustainable development of tourism. Proceedings of $\mathrm{V}$-th International conference. Zabrze 2008 [In Polish only].

21. HEWISON R., The Heritage Industry, Methuen, London 1987.

22. JEDDRYSIAK T., Cultural tourism in former industrial buildings - general issues. Turystyka kulturowa. Nr 6/2011 (czerwiec 2011),

23. KRUCZEK Z., Industrial routes as products of specialized tourism. Zeszyty Naukowo-Techniczne. Stowarzyszenie Inżynierów i Techników Komunikacji. Seria Materiały konferencyjne. Zeszyt nr 74, Kraków 2005.

24. LENARTOWICZ K., OSTRĘGA A., Revitalisation of Post-Industrial Areas Through the Preservation of 
Technical Heritage in Poland. AGH Journal of Mining and Geoengineering. 36 2/2012.

25. RADWAŃSKI A.R., The Ignacy Łukasiewicz Memorial Museum of Oil and Gas Industry in Bóbrka and historical monuments of petroleum and salt industries in the vicinity of Krosno (the Polish Outer Carpathians), GEOTURYSTYKA 3 (18), 51, 2009.

26. RICHARDS G., Cultural tourism trends in Europe: a context for the development of Cultural Routes. In: KhovanovaRubicondo K. (ed.), Impact of European Cultural Routes on SMEs' innovation and competitiveness. Strasbourg: Council of Europe Publishing, http://www.coe.int $/ \mathrm{t} / \mathrm{dg} 4 /$ cultureheritage/culture/routes/StudyCR_en.pdf, 21, 2011.

27. MIEG H.A., OEVERMANN H., Industrial Heritage Sites in Transformation. Clash of discourses, Routledge, 2014.
28. SIKORSKA E., Oil Trail. In: Development of industrial tourism. Promotion of Carpatho-Galician Oil Route. Conference materials. Materiały pokonferencyjne. Jasło, 2007 [In Polish only].

29. SZEWCZYK A., Sowliny - the Center of the Petroleum Industry at the Very West End of the Carpathian-Galician Petroleum Route. Current Condition, Problems with Revitalization. AGH Journal of Mining and Geoengineering. 36, No. $1 / 2012$

30. KOTLER P., KEVIN L.K., Marketing Management. Prentice Hall, $14^{\text {th }}$ edition, 2000.

31. WALAS B., KRUCZEK Z., Marketing. Wydawnictwo Szkolne i Pedagogiczne, Warszawa 2013 [In Polish only]. 